\title{
Paradise Imagined: Songs of Scots Gaelic migrants in Australia, 1850-1940
}

\author{
Ruth Lee Martin
}

\begin{abstract}
Life is more than separate events; it incorporates the quality of duration, of passage through time. Buffeted by change, we retain traces of our past to be sure of our enduring identity. ${ }^{1}$
\end{abstract}

The past is important to us, for it makes us who we are in the present, and who we strive to be in the future. Our past contains the essence of who we are: basically a work in progress as we shape and reshape our individual and collective identities. A significant contributor to this process is place-the geographic landscape - saturated with rich layers of cultural memory, in which we are immersed, and which contributes to creating who we are and, indeed, who we are becoming. This paper examines the connection between Scottish migrants and their native landscape through songs written in Australia between the 1850s and the 1930s by migrant songwriter-poets in the Scots Gaelic language. One of the recurring themes that these Scottish Gaelic bards ${ }^{2}$ have expressed in the songs they composed in Australia is an overwhelming loss of place, $^{3}$ and they remind us of the intricate and intimate connections between landscape and people. These cianalas, ${ }^{4}$ or 'homesickness songs', were composed by bards who were driven from their homeland, either involuntarily or through necessity, and who emigrated from the Highlands and islands of Scotland.

The early bards who emigrated to Australia from the mid 1800s are quite difficult to trace, as the information about them is scant. Most of them published their songs in newspapers of the day such as the Australian version of An Teachdaire

\footnotetext{
1 Lowenthal 1975, p. 9.

2 I have chosen to use the term 'bard' in the sense that it denotes music and text combined, rather than the word 'poet', which in English suggests text only, or 'composer', which seems to place emphasis on the music. In its original context, the word 'bard' referred to professional poets who wrote panegyrics and eulogies to their chiefs. Until recent times, nearly all Gaelic poetry was sung. John MacInnes says: 'A contemporary bard in a crofting township is the distant heir of the poets who once enjoyed the patronage of the kings of Scotland and the great magnates of the kingdom, and will make songs, as of right, on issues of national and international import' (MacInnes, J. 2006, Dùthchas Nan Gàidheal: Selected essays of John MacInnes, Edited by Michael Newton, Birlinn, Edinburgh, p. 3).

3 The two other recurring themes are loss of family and community, and loss of language.

4 Cianalas is a Gaelic word meaning melancholy, sorrow and/or homesickness (Dwelly, Edward 2000, Illustrated Gaelic-English Dictionary, Birlinn, Edinburgh, p. 193). There is often a feeling of sadness for a past that is lost. There is a whole body of migrant songs speaking of cianalas or homesickness, including the songs of Iain Archie MacAskill written in Australia.
} 
Gaidhealach (The Gaelic Messenger), printed in Hobart in 1857, or sent their songs back home to be printed in newspapers such as the Oban Times. From the information gleaned from the poetry, they all appear to have been born in the Highlands and islands as their descriptions of events and landscape are extraordinarily detailed and could only come from firsthand knowledge. From the song texts it is also clear that some were evicted, or had close ties to evicted people, and a sense of indignation at the injustices perpetrated against the Gaelic community comes through in some of the songs such as this one from Eoghan Mac-an-t-Shaoir (Ewin MacIntyre) published in An Teachdaire Gaidhealach $(A T G)$ in June 1857:

'Snam b' ann chum an

fheachda no ghleachd ri ar namheid

Bhiodh uaislean ar cinnidh 'gar sirreadh mur b' abhaist

Gu onair ar duthcha a's cliu do na Gaidheil

Cha ' $n$ fhaicte cho craiteach ar cairdean fo bhron.

\section{It wasn't for vice or bad behaviour}

That they are ejecting us from our homes and country

But for the extent of hatred in their two-fold hearts

Who are ruling our country and refusing to give us food.

There is very little factual information about the bards themselves, and to further complicate matters pseudonyms are sometimes used such as that used by the bard who goes by the name Creagan An-Fhithich (Raven's Rock). ${ }^{6}$ Another bard signs himself simply as 'A Highlander from Penola, South Australia'. ${ }^{7}$ The emigrant bards appear to have settled in many parts of Australia, from Kanowna in the goldfields of Western Australia to Lake Eliza in South Australia, Geelong and Melbourne in Victoria, and Armidale in New England and the Riverina district in New South Wales.

\footnotetext{
5 All of the Gaelic-language spelling is copied exactly from the originals. This means of course that accents are missing, particularly from the older newspaper, An Teachdaire Gaidhealach; however, it seems best practice to leave the Gaelic spellings as they were originally published. This includes names.

6 He has two songs published in the Australian version of An Teachdaire Gaidhealach (ATG), one being a praise poem for the countryside he has left behind and the other an elegy for a Highlander who died in Hobart in 1856.

7 Penola is a township about $400 \mathrm{~km}$ south-east of Adelaide and is mainly known as a winegrowing region. It has a long history of Scottish settlement from the 1840s (<http://www.southaustralianhistory.com.au/ penola.htm $>$ ).
} 
Two Highland bards whose lives are documented are John MacLennan (b. 1861), who emigrated from Inverasdale on the north-west coast of Scotland to Brisbane in 1885, and the bard, piper and World War I veteran Iain Archie MacAskill (b. 1898), who emigrated to Australia in 1924 under the WA Government Group Settlement Scheme from the small island of Berneray, North Uist, in the Outer Hebrides. Although their lives took quite different paths, both write with a strong love of the landscape of 'home'. The song texts composed by Iain Archie MacAskill $^{8}$ (or John Archie as he is known is his family circle) are especially caught up in memories of landscape - and his poetic descriptions are full of local placenames and the geographic features of Berneray that he knew and loved so well. No matter what the cause of emigration, however, one thing is clear in the compositions of the bards, and that is the enduring love of the landscape of home.

Homeland, not surprisingly then, takes a prominent role in the minds of the bards here in Australia, so much so that the current landscape in which they are immersed seems insubstantial and scarcely worth noting. It is not insignificant that of the Gaelic songs written in Australia only a very few make any mention of Australia at all, and none in a particularly positive way. ${ }^{9}$ References to Australia are rare and always fleeting.

Indeed, John Archie acknowledges this very poignantly in his song 'Oran $a^{\prime}$ Chianalais' ('Song of Homesickness'), in which the loveliness of the Australian landscape on an early morning seeps into the bard's consciousness almost unawares before he rather casts it aside. His longing for homeland is too intense ${ }^{10}$ to allow consideration of the beauty around him in his new country: ${ }^{11}$

\footnotetext{
8 The song texts were edited and published as An Ribheid Chiuil with extensive notes by his cousin Alick Morrison.

9 The songs mentioned in this article will be published in full in my forthcoming book, Gaelic Songs of Australia, a collection of 45 Gaelic Australian songs (set in musical notation) complete with a critical introduction.

10 It is a curious thing but I have not as yet discovered any praise poems in Gaelic to the Australian landscape, although there are two that praise New Zealand in Donald Fergusson's book (1977, Beyond the Hebrides: Including the Cape Breton Collection, Lawson Graphics Atlantic, Halifax, pp. 332-4). It may be that I just haven't discovered them yet, or it may be that the New Zealand landscape (especially the South Island), in its rugged geographic formation, was closer to the Gaelic migrants' idea of what a landscape should look like. This is certainly an interesting theme for future exploration.

11 MacAskill, Iain Archie 1961, An Ribheid Chiuil, Edited by Alick Morrison, Learmonth \& Son, Stirling, pp. $74-5$.
} 
The mhaduinn sgiamhach 's a' ghrian ag eirigh

Air uchd nan sliabh chas mar fhiamh $a^{\prime}$ cheitein;

An driùchd a' deàrrsadh air bhàrr nan geug ann

'S an eunlaith triall as air sgiathan gle-gheal.

Cha deàn mi sùgradh ri ciùin an àite...

Gach nì tha 'm shùilean gun diù gun chàil dha,

'S nach mòr nach tionndaidh mo chùl gu bràth ris.
The morning is lovely and the sun is rising

On the brow of the steep hill like a glimpse of May;

The dew is sparkling on the tops of the branches there

And the birds are flying with bright white wings.

I am not uplifted by the peace of the place...

The sights before my eyes do not engage me

I would almost turn my back forever on them.

In the song 'Oran Ionndrainn' ('Song of Longing'), John Archie describes the machairs, or plains, of Australia as oppressive under the fierce sun: ${ }^{12}$

Mo chridhe trom, 's duilich leam

'S muladach mar tha mi,

An tir na machrach

iargaineach

Fo theas o'n ghrian tha deàrrsadh.
My heart is sore, and I am sad

And sorrowful

In the land of the

burdensome machairs

Under the heat of the blazing sun.

In his article 'Reflections on exile', Edward Said describes the severe emotional toll brought about by the severance from home and homeland as 'the unhealable rift forced between a human being and a native place, between self and its true home: Its essential sadness can never be surmounted' ${ }^{13}$

Certainly this 'unhealable rift' is very much evident, and indeed is a central theme, in the texts of Australian Scots Gaelic song where the bards express

12 Ibid., p. 67.

13 Said, Edward 2000, 'Reflections on exile', Reflections on Exile and Other Essays, Harvard University Press, Cambridge, Mass., pp. 173-86, at p. 173. 
and share a persistent, and oft times overwhelming, sense of grief and loss of homeland that resulted from their emigration - often without any real choicefrom the Highlands and islands to Australia in the mid nineteenth century.

Scots Gaelic migration to Australia began to really get under way in the turmoil of the Highland Clearances in the mid nineteenth century, ${ }^{14}$ when many Highlanders and islanders began the long and sometimes hazardous sea voyage to Australia. Many of these early migrants were forced from their hereditary lands due to a complex number of factors that worked together to cause widespread poverty and misery. The hereditary relationship in Scotland between the landscape, landlord and people was going through a phase of rapid change. Agricultural reform began sweeping through the whole of Scotland (including the Scottish Lowlands) ${ }^{15}$ from the early 1800s and affected the very poorest group of people struggling to subsist on small plots of land while paying rent to landlords. These subsistence farmers, or crofters, were evicted from the land, which was then given over to larger, commercial enterprises. In the Highlands, large-scale sheep farms were set up and profits were made for landlords and their tacksmen. ${ }^{16}$

It is perhaps surprising to the modern-day reader that living conditions in the Highlands and islands of Scotland were so grim that people were literally starving to death. Many of the poorest - through being removed from their homes and lands - were living in the most appalling and squalid conditions with the result that destitute Gaels without sufficient food, shelter or indeed clothing ${ }^{17}$ were living on the absolute margins of sustainable life. A minister from the island of Uist, obviously shocked by the condition of the people around him, said that he had 'never witnessed such countenances - starvation on many faces - the children with their melancholy looks, big-looking knees, shrivelled legs, hollow eyes, swollen-like bellies. God help them, I never did witness such wretchedness.' ${ }^{18}$

14 Until the mid 1800s, Canada was the preferred destination (Devine 1999, p. 245).

15 While Clearances did take place in the Lowlands, they were particularly harsh in the Highlands (Kennedy, Kate 2011, The Lowland Clearances and the transformation of southwest Scotland, Report on speech given by Tom Devine, 26 May 2011, viewed 15 May 2012, <http://www.royalsoced.org.uk/cms/fileàs/events/ reports/2010-2011/lowland_clearances.pdf >).

16 The definition of the word 'tacksman' from the Collins English Dictionary is 'a leaseholder, esp a tenant in the Highlands who sublets' (<www.collinsdictionary.com/dictionary/english/tacksman $>$ ). For a comprehensive account of the Highland Clearances, see Richards, Eric 2008, The Highland Clearances: People, landlords and rural turmoil, Birlinn, Edinburgh; or Devine, T. M. 1988, The Great Highland Famine: Hunger, emigration and the Scottish Highlands in the nineteenth century, J. Donald, Edinburgh.

17 Clothing was often mere rags. Some people tried to make clothes from the empty bags of meal, and many went barefoot in all weather (MacLeod, John 1996, Highlanders: A history of the Gaels, Hodder \& Stoughton, London, p. 198).

18 Quoted in ibid. 
There was a generally held view that the Highlands and islands were overpopulated and this excess of population needed to be culled; ${ }^{19}$ one way of doing this was for landlords to evict the small tenantry and send them off to Canada, America or Australia, thus excising them neatly from the landscape.

A constant source of frustration for Highland landholders was the difficulty of detaching people from their homelands. As Prebble states when discussing the formation of the Highland and Island Emigration Society:

In 1851 something like planned emigration was evolved. It was by compromise, of course, with the Government acting like a parent, giving advice and some financial assistance to private emigration societies which were expected to find the bulk of their funds in the pockets of the public. The Board of Supervision, the central administrative control for the Poor Laws, had been in favour of emigration for some time, and was in a constant state of irritation over the people's reluctance to leave their homes. It was of the light-headed opinion that the best way to convince them of the necessity of emigration would be to put the burden of immediate poor relief on the shoulder of local authorities. This would soon starve the Highlanders into submission. ${ }^{20}$

While there was no choice for some of these migrants, others were under enormous pressure to provide a future for themselves and their children free from poverty. ${ }^{21}$ They came to Australia to forge better lives for themselves and their families, their hopes fuelled by advertising, stories published in pamphlets and newspapers, and letters 'home' of a land of opportunity and plenty, and with the ever present lure of gold. But even those who came to find a better life for themselves and their families felt the desolation of loss of homelandsomething that stayed with many for the rest of their days, as their songs attest.

19 Sir Charles Trevelyan, Chairman of the Highland and Island Emigration Committee (set up to give financial assistance to people wanting or needing to migrate), believed in the early 1850s that there was a 'surplus' population in the Highlands and islands of around $30000-40000$ people (Devine 1999, p. 251). 20 Prebble, John 1963, The Highland Clearances, Penguin Books, London, p. 200. The two most important men in the Highland and Island Emigration Society, Sir Charles Trevelyan and Sir John McNeill, had both been active in the promotion of emigration as the solution to social problems in the Highlands for some time (Devine 1999, p. 251). Trevelyan was a complex man, but his view of the necessity to withdraw all aid to starving families in order to force them into compliance in regards to emigration seems extremely harsh and inhumane by any standards.

21 It was only in 1886 that a rather limited and unsatisfactory Crofter's Act came into existence, giving at least some security to statutory crofters. For a detailed account, see Richards, The Highland Clearances, pp. $384-8$. 


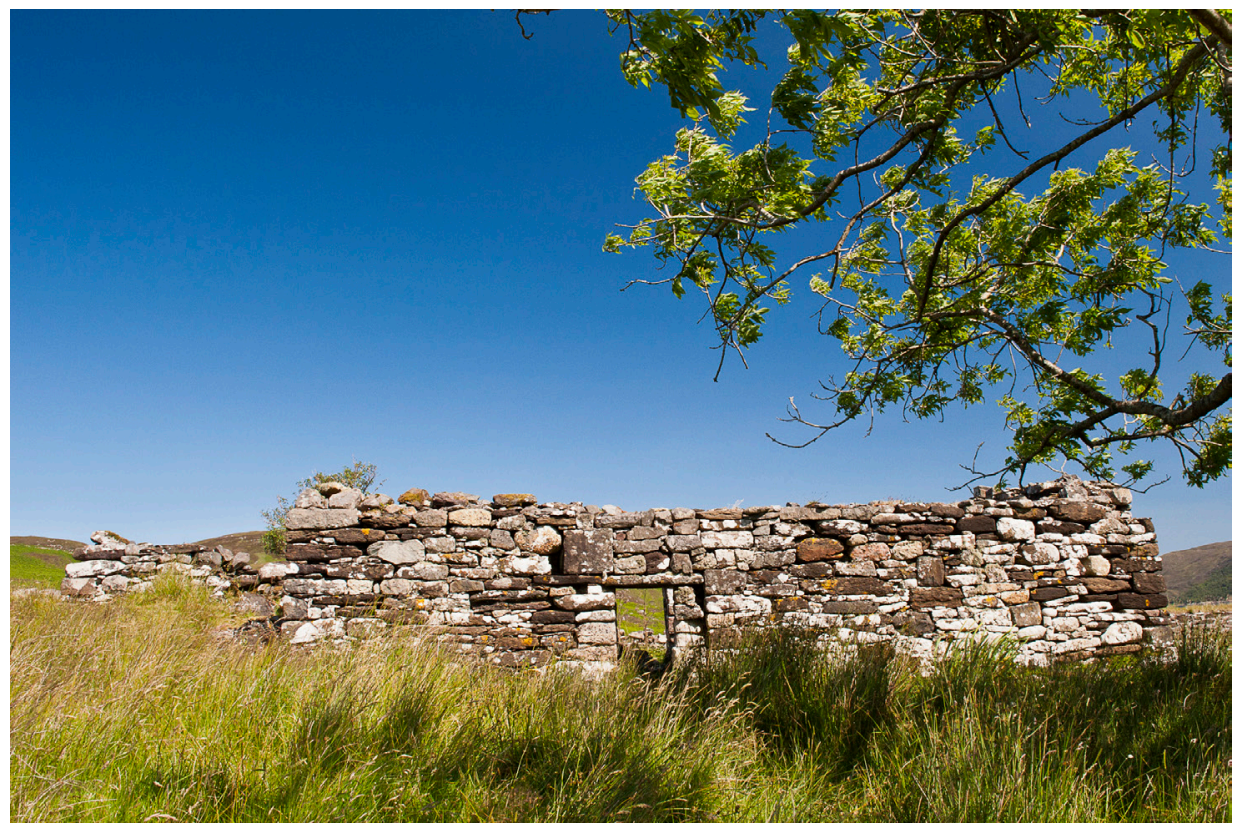

Figure 1 Abandoned house at Boreraig, Isle of Skye, from clearance that took place in 1853 by agents of Lord MacDonald

Photograph courtesy of Bradley Cummings

These songs are full of longing for 'home' — not just for the communities and families in which people had been nurtured but also a powerful longing for the landscape itself in which they were reared. They demonstrate a connection with place that is both profound and enduring. As poet and scholar Derick Thomson states:

The commonest theme of Gaelic verse in the nineteenth century is that of 'homeland'. This was no doubt to be expected in a period of upheaval and uprooting, much of it of an involuntary nature, whether people were forced to migrate by physical action or by economic circumstances. The homeland is seen primarily in a nostalgic light: a place of youthful associations, family and community warmth, a Paradise lost. ${ }^{22}$

In these songs the description of landscape is arresting, for the landscape described in no way represents the real landscape left behind; it is rather a constructed landscape of the mind. It is a landscape of the imagination, where time seems to be caught in perpetual late spring, the countryside bathed in golden light. This is not a landscape where one has a sense of being a passive onlooker, awed and overwhelmed by nature in its raw state, but rather the

22 Thomson Derick 1974, An Introduction to Gaelic Poetry, Victor Gollancz, London, p. 223. 
landscape of these songs is one that is fully revealed in its intimate association and interaction with the people who live in it - a landscape that beckons and invites into itself. It explodes with life and vitality, a place of boundless, directed energy, moving joyfully and ceaselessly towards procreation, life and renewaland its people are an integral part of it.

John Archie was desperately unhappy in Australia and, after he put in backbreaking toil to clear his plot of land, the bank foreclosed on his property after a severe drought in $1931 .^{23}$ The one thing that gave John Archie solace through these difficult times was his imagining of home - the landscape of the little island of Berneray in the Outer Hebrides - so lovingly described in his songs. This landscape has a potent life force that he describes in vivid detail, clearly demonstrating his intimate connection with it, and his respect and love for it:

\section{Is damh na cròice neo-stòlda séideachd}

Air cnocan móintich 's e tòir nan éildean.

Tha ' $m$ bradan tarrgheal 'san tan'-abhuinn ghléite

Is e cluich gu lean-shamhach gur dearg air leum e;
The stag with antlers is restless, snorting,

On moorland hillocks the hinds he's seeking.

The greyish salmon in the shallow river

Is now calmly playing before madly leaping

* Air fonn: Fhir a' Bhàta [To the tune: The Boatman]'. MacAskill, An Ribheid Chiuil, p. 88.

Or consider this reflection on the home country from Iain Dubh Mac Dhomhnull 'ic Iain, known as John MacLennan:

Tha crodh is caoraich air raointean fàsail,

Na laoigh's na h-uain ruith mu'n cuairt ag àlais;

Tha iasg is sgadan gu tric 'g an tràilleadh,

'S cearc-fhraoich is liathchearc air sliabh'sa bhràighe.

Hug i ho ro, etc.
There are cattle and sheep in desolate fields,

Calves and lambs running around and breeding;

Often are fish and herring caught by trawlers,

And the moor-hens and grey hens on the slopes of the braes.

Hug i ho ro, etc. *

* Air Fonn: Tha mi fo ghruaim rinn mo luaidh mo thréigsinn [To the tune: I'm so sad as my love has deserted me]'. MacLennan, John (Iain Dubh Mac Dhomhnull 'ic Iain) 1937, Duanagan agus Sgeulachdan Beaga, Alex Maclaren, Glasgow, p. 4.

23 John Archie's life ended tragically by illness brought on by stress and poor nutrition in 1934 at the age of thirty-six, and he was buried in the Karrakatta cemetery in Western Australia. He was never forgotten by his family back in Scotland. In 2010 they raised enough money to bring his remains back to his beloved Berneray where he was reburied in the small local cemetery next to his parents. 
The songs portray the abundance and variety of plant life in the imagined landscape of these bards in a most descriptive way. There are tall, straight, warrior-like oak trees; slim-branched and fragrant birch; soft tresses of the noble pine; and flowers abound: primroses, daisies and heather. It is a landscape replete with animals: cattle grazing or playing on green slopes, or deer that roam freely over hill and moor. It is also a landscape filled with the joyful singing of birds of all kinds: the thrush, skylark, cuckoo, geese and ducks.

For example, this extract of a song recalling home, 'Na Tulaichean Boidheach' ('The Lovely Hillocks'), by Seumas Mac 'Ille-Mhaoil (James MacMillan) from Kanowna, Western Australia, published in Scotland in $1900,{ }^{24}$ makes this point explicit:

Glac-nan-laogh tha fo dhuilleach

Air uilinn dà chnoic

Far an cluinnear an smeòrach

'Seinn ceòl ann gun sprochd;

Tha an uiseag air phreasan,

Tha nead aic' air ghloc,

$A^{\prime}$ chuthag 's gug-gug aic'...
The gorge-of-the-calves is covered with foliage

On its shoulder two hills

Where the thrush can be heard

Musically singing without gloom;

The skylark is in the briar-bush,

She has a nest in the gorge,

The cuckoo singing gug-gug...

A real sense of movement and abundance in the landscape is drawn into this song - again from John Archie:

Théid ianlaith nan speuran

Air féill ann as ùr,

Dol thairis air sléibhteann

'Nan ceudan le sùnnd;

$B i$ ' $n$ cathan's an giadh ann

Glé lionmhor 'na chùl

'S an eal' air an Tràigh

'S lachainn-bhlàr air

LochBhrùst.
All the birds of the sky

Joyfully celebrate anew

Crossing slopes

In their hundreds;

Barnacle and other geese

Will be plentiful in the Cùl

Swans on the sea-shore

And coots on Loch Brusta.*

\footnotetext{
* 'Air fonn: Eilean an Fhraoich [To the tune: Island of Heather]'. MacAskill, An Ribheid Chiuil, p. 61. In his notes on John Archie, poetry editor Alick Morrison comments that Loch Bhrusta, a freshwater lake, is well known for its abundance of birdlife including swans (p. 121).
} 
This dramatic and dynamic landscape contains all manner of creatures (useful for sustaining human life) and is in a natural, rightful balance when stewarded by its people: strong, brave and cheerful fishermen, hunters and cowherds and gentle, warm, hardworking women-maidens or milkmaids - without blemish. There are also many references to brave stalwart ancestors and heroes. This landscape is indelibly marked by the names given to it by its people so prevalent in the songs, and by numerous commemorative cairns ${ }^{25}$ dotted about the landscape.

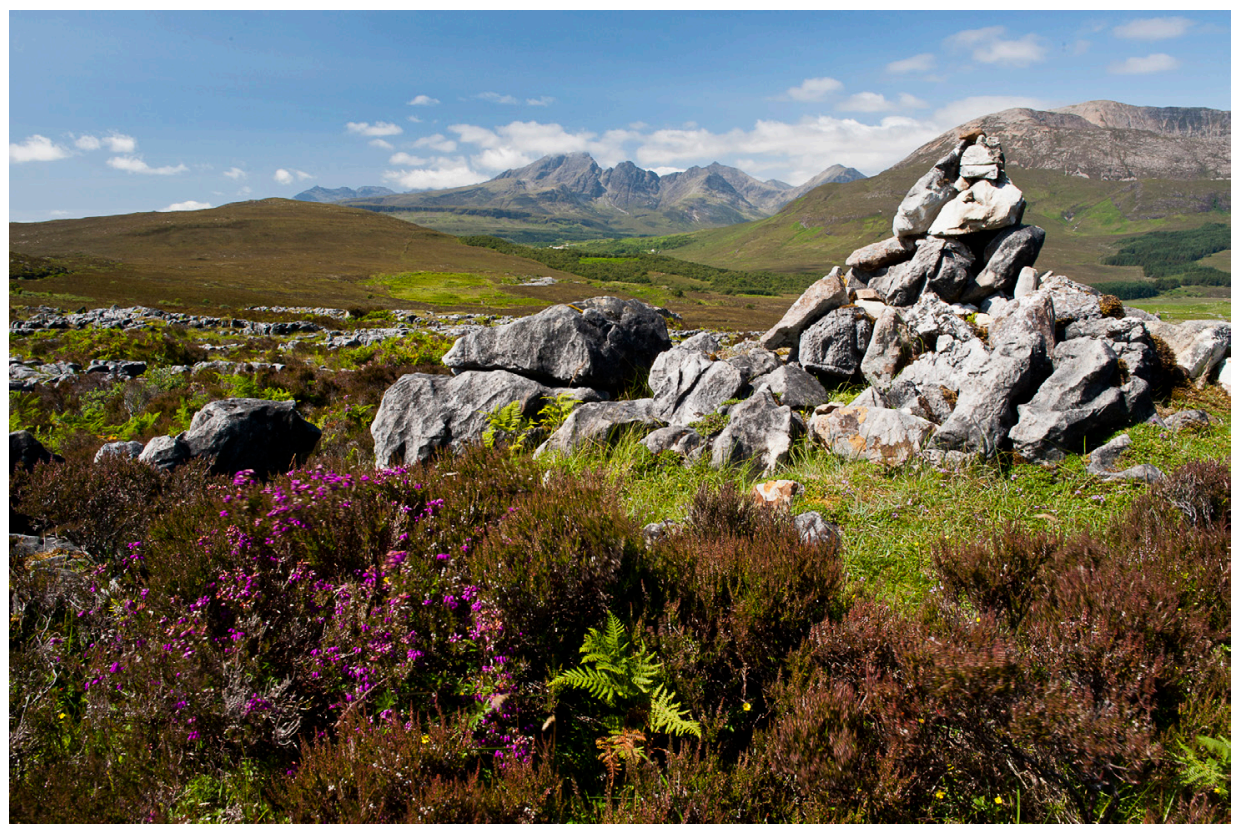

Figure 2 Commemorative cairn in the foreground from the track to the cleared houses of Boreraig, Isle of Skye

Photograph courtesy of Bradley Cummings

It is a land where there is an abundance of clean, fresh water-something no doubt especially fondly remembered by the Australian Gaelic bards in the dry Australian climate. These bards also remind the Gaelic community of the healthgiving benefits of the water that is found in the homeland:

25 Most Scots know what a cairn is as the Scottish landscape is liberally sprinkled with them. For other readers, a cairn is a pile of stones heaped up in a mound as a landmark or to commemorate an event. 
Tha comhnaird cheutach nan sgathan speur-ghorm,

De $d h^{\prime}$ uisge gle-ghlan, mu steidh nam beann,

'S tha sruithean uasal 'tigh'n annta's uapa,

'Sa' dol le luathghair do'n chuan nan deann;
The splendid level grounds reflect the blue sky,

Of fine, pure water around the base of the bens,

And there are noble streams coming into them and from them,

And going exultantly into the ocean with a rush; ${ }^{*}$

* 'Air Fonn: Coire-Cheathaich [To the Tune: The Misty Corrie]'. Creagan An-Fhithich (Raven's Rock) 1857, 'Duan Na Smeoraich 'An Tir Chein' [The Thrush's Song “Far Away Land”]', An Teachdaire Gaidhealach, [Hobart], March 1857, p. 4.

John Archie is forthright in his views about the significance of water in the landscape of Berneray:

Gur tric air mo smuaintean

Na bruaichean tha grinn,

Le fuarain ghlan-fhuasgailt

'Tha luath-ruith le glinn;

Tha 'n t-uisge cho luachmhor

'S nach d'fhuaras da prìs,

Toirt neart agus suaimhneas

Do 'n t-sluagh ann air tir.

\section{I often think}

Of its beautiful slopes

With open fresh springs

Tumbling through the glens

The water is so precious

That it has never been priced

Giving strength and security

To the people in our land.*

* 'Air fonn: Eilean an Fhraoich [To the tune: Island of Heather]'. MacAskill, An Ribheid Chiuil, pp. 61-2.

This theme connects the natural elements of the landscape with the health of its inhabitants. It is particularly significant, for it not only shows that in the minds of the Gaels an essential relationship exists between themselves and their landscape in terms of mental and spiritual wellbeing (which is perhaps what could be expected), but it also emphasises and reminds of the importance of the connection between people and landscape in terms of physical health and wellbeing. 
The song from Brisbane bard John MacLennan takes up this theme. It is significant that the chorus is reiterated many times throughout a performance of this song: ${ }^{26}$

Tha mi tinn, tinn, tinn, tha mi tinn gun bhi slàn,

Mi bhi fàgail na tir gun fhios an till mi gu bràth.
I am sick, sick, sick, I am sick without health

I will be leaving the land without knowing if I'll ever return.

Many of the songs tell of the emotional strains of being separated from a familiar landscape, resulting in negative emotional states such as a lack of joy, melancholy, heavy heartedness and so forth, and, like John MacLennan, they also speak of the physical affects this has on them such as feeling 'tinn gun bhi slàn' (sick without health). This acknowledges that separation from homeland can have such devastating consequences that not only affect emotional states but also have the power to affect the physical state.

The idea of health emanating from the physical landscape can be seen in the following song, 'Soraidh Bhuam gu Barraigh' ('Farewell to Barra'), composed by a bard from the island of Barra who called himself 'The Article':

Soraidh bhuam gu Barraidh

Eilean's maisich tha fo'n ghrèin

Far an tric an robh mi sùgradh

's le sunna a ruith na sprèidh

Gur lionmhor lus tha fàs fo'n

drùchd

Is deallt air uir as dhèidh

A bheireadh slainte is

mùirneal dhuit

Air maduinn chùbhraidh chèit'
My blessings on Barra

The most beautiful island under the sun

Where I often played

And happily herded the cattle

Plants abound beneath the dew

And the fine rain on the soil

On a May morning

Gives forth both good health and happiness.

26 'Air fonn: Thug mi gaol dhuit Iain Bhàin [I gave my Love to Fair-Haired Iain]'. MacLennan, Duanagan agus Sgeulachdan Beaga, p. 2. 
Significantly enough, in this song the author later talks of being alone in 'An Astràilia nan craobh' (in Australia of the trees), perhaps in the contemporary mind-set no bad thing at all, but to the Gael an over abundance of trees in the landscape spoke of desolation: a land bereft of people and animals. ${ }^{27}$

A further example of this sense of unease caused by a landscape that supports an abundance of trees can be found in the expressive poetry of Màiri NicDhòmhnaill (Mary MacDonald). In the poem 'Craobhan' ('Trees'), she speaks of a landscape without its people resulting in the growth of trees that are ' $a$ ' mùchadh a' ghlinne' (choking the glen) and "s $a^{\prime}$ dubhadh na grèine' (darkening the sun). ${ }^{28}$

Another interesting aspect of the Australian Gaelic songs is the way in which various aspects of the landscape are treated in an anthropomorphic way. For example, a little later in the verses composed by Creagan An-Fhithich (Raven's Rock), in speaking of the wind, he says:

Air chiabh nan stucan bu mhor mo shugradh

Le caithream shunntach fheadchiuil na chrios.
The wind making a musical sound

Lively, dancing, whistling around the peaks. *

* Creagan An-Fhithich (Raven's Rock), 'Duan Na Smeoraich 'An Tir Chein", p. 4.

And later still, the trees are described as 'noble' and 'gallant' and likened to brave warriors:

'Nan geugaibh comhard bu
chlu-mhor cosan

'Nan cnaimheach oga bu domhail druim;

'S ged 'ni an tuath-ghaoth an aitreabh 'luasgadh

Cha ghabh iad fuathas aon uair, na suim
These are the gallant trees of the pines

Clad in a foliage that is gallant and noble

The north wind will not shake their abode

These warriors will not take fright.*

* Ibid., p. 4.

27 Another good example of this sense of unease generated by a landscape of thick woodland, or forest, is given by the bard John MacLean, who settled in Pictou County, Nova Scotia. He composed a song in 1819 called ' $A$ ' Choille Ghruamach' ('The Gloomy Forest') in which he describes the overwhelming sense of alienation with his physical surroundings (Gillies, Anne Lorne 2005, Songs of Gaelic Scotland, Birlinn, Edinburgh, p. 249).

28 Kerrigan, Catherine (ed.) 1991, An Anthology of Scottish Women Poets, Edinburgh University Press, Edinburgh, pp. 98-9. 
There is also this delightful and evocative description of Loch Ewe from John MacLennan:

Gu'm faic thu Loch Iubh gu

mùirneil farsuinn,

Le acarsaid chiuin chiuin's

gach lùb is camus

Mu'n cuairt air gach taobh gu

cùbhraidh, fallain,

Tha'n dùthaich eireachdail, bhòidheach.
I can see Loch Ewe with its joyful expanse,

With a quiet anchorage and every bend and siding

Around on all sides sweetly, healthy,

The country is beautiful, and lovely.*

* 'Air Fonn: Muile nam Mòrbheann [To the Tune: Mull of the High Bens]'. MacLennan, Duanagan agus Sgeulachdan Beaga, p. 33.

Of course, a sense of mental anguish runs through many of the songs as well, clearly demonstrating the overwhelming sense of pain generated by separation from the country of birth such as can be found in the following verse-basically a cry from the heart:

Lochabar, Lochabar, Lochabar, nan ard-bheann,

Nan stuchd-bheanna casa, 's nan glacagan fasaich,

'S e $d h^{\prime}$ fhag mi fo eislein gur eiginn dhomh $t^{\prime}$-fhagail

$S^{\prime}$ bhi triall as an aite rinn $m^{\prime}$ arach's mi og!

Taobh Loch Liobhunn.
Lochaber, Lochaber, Lochaber, of the high mountains,

Of the steep mountain peaks, and the deserted gorges,

What left me in grief is that I had to leave you

And to leave the place that reared me in my youth!

Beside Loch Leven.*

\footnotetext{
* Mac-an-t-Shaoir, Eoghan (Ewin MacIntyre) 1857, 'An T-Abrach A Fagail A Dhuthcha [A Lochaber Man Leaving His Country]', An Teachdaire Gaidhealach, [Hobart], June, p. 6.
} 
The effect of separation from homeland is summed up in devastating succinctness with these two lines by John Archie:

'S e gath a' chianalais pian gun tròcair

Tha losgadh $m^{\prime}$ inntinn, mo chridh' 's mo threòir uam.
The arrow of homesickness causes a merciless pain That burns into my mind, my heart and my strength.*

\footnotetext{
* 'Air fonn: Fàill il lo agus ho ro eile [To the tune: Fàill il lo agus ho ro eile]'. MacAskill, An Ribheid Chiuil, p. 74. *The words 'Fàill il lo agus ho ro eile' are vocables and do not contain any semantic meaning. To say they are meaningless is problematic for they certainly identify many song tunes, as well as provide an opportunity for communal engagement in the singing. See John MacInnes's article 'The choral tradition in Scottish Gaelic Songs' (MacInnes, Dùthchas Nan Gàidheal, pp. 211-29) for an interesting commentary on the use of vocables in Gaelic song.
}

As has been demonstrated, the landscape of home is dynamic, with ample variety and colour. It is a land teaming with life and abundance - in full bloom - vigorous and fertile. Stags are looking for mates; salmon are spawning and calves and lambs are frolicking on green slopes. It is a land of high, heathery mountains, of verdant glens, a land of machair ${ }^{29}$ of flowery fields shining and golden - gleaming under the dew - and fragrant islands in seas abounding with fish.

But where, in all this fulsome description, is the landscape of reality? Where is the landscape that is often harsh and unforgiving - a land of long, bitter winters, chilling cold, unending rains, poor, thin soils and rough ground? This landscape has been erased from the individual memory of the bards and, through the songs cycling in the public sphere, erased also from the collective memory of the Gaelic community in Australia. So, just as these people were erased from their landscape, so too they in turn erased the harsh physical landscape from their minds and replaced it instead with a utopian vision of homeland.

Lowenthal makes the important point that:

The tangible past is altered mainly to make history conform with memory. Memory not only conserves the past but adjusts recall to current needs. Instead of remembering exactly what was, we make the past intelligible in the light of present circumstances... Above all, memory transforms the past we have known into what we think it should have been.

29 The best description for this term comes, I think, from Dwelly (Illustrated Gaelic-English Dictionary, p. 620): 'Long ranges of sandy plains fringing the Atlantic side of the Outer Hebrides. They are closely covered with short green grass, thickly studded with herbs of fragrant odours and plants of lovely hues.' 
Selective recall eliminates undesired scenes, highlights favoured ones, and makes them tidy and suitable...we mask diversity and collapse countless disparate images into a few dominant ones. ${ }^{30}$

To the Scots Gaelic migrant looking back, the glasses are more than rose-tinted, for there are no half measures here in the intensity of love for homeland.

'This is a past that has been reimagined - it is not the past as it was: The past we know about is not, in any case, a present that was ever experienced.' ${ }^{31}$

This was not a landscape based on the reality of poverty and destitution, but rather a paradise, not so much lost - for it never existed - but rather a paradise imagined; re-imagined, re-created and revisited each time one of these songs was sung.

The power of song is not restricted to text alone, for so much that is culturally meaningful is carried on the tunes themselves. These are significant because they are pre-existing tunes handed down through the oral tradition, around which the bard crafted his or her words. ${ }^{32}$ For example, in speaking of the death of Uist bard Malcolm Macaskill, Alick Morrison makes the comment that ' $[\mathrm{t}]$ he bard possessed a fine repertoire of Gaelic melodies...In the framework of these tunes, the bard with great skill, inserted his poetic compositions' ${ }^{33}$

New song texts then were often set to older, traditional tunes and many of the Australian Gaelic songs follow this practice, showing that this link with tradition was an important one in the construction of their verses. So although the Australian Gaelic songs were published through the medium of newspapers and books, they retained strong links with the oral tradition. At the top of the new text, the bard would indicate which song tune to use with the words: 'Air Fonn...' (literally 'On the Tune...'). For example, see the following from the beginning of John Archie's song 'Moladh Tir Na Gaidhlig' ('Praising the Land of Gaelic'):

Air fonn.-Fhir a'bhata.

[To the Tune.-The Boatman]

- after which he gives his new text.

\footnotetext{
30 Lowenthal 1975, p. 28.

31 Lowenthal 1975, p. 25.

32 Both men and women composed songs in the Gaelic tradition, and in fact there are some groups of songs mostly composed by women such as the Waulking songs sung while pulling the homespun cloth. In this collection of Australian songs I have gathered, so far, I have not found any songs certain to have been composed by women. It is entirely possible that they have not yet been discovered.

33 MacAskill, Malcolm n.d., Orain Chaluim: Being the poems of Malcolm MacAskill bard of Berneray Harris, Edited by Alick Morrison, Alexander MacLaren, Glasgow, p. 25.
} 
The tunes provided the framework for the new words and became in a real sense a bridge to the past, carrying an accretion of cultural meanings with them and transferring these to the new texts, in the new country. They are carriers of geographic location, often associated with the particular place in which they were composed, sung and passed around the local community. They are taken up by a new bard, or bards, and fitted with new texts, spawning variants of the melody's phrases and rhythms as they pass through many life cycles - all the while accruing new cultural layers as well as carrying older cultural layers along with them. This referral, or intertextuality, ${ }^{34}$ performs significant cultural work and the tunes are extremely important because of it.

Gaelic scholar John MacInnes, in his essay 'The panegyric code in Gaelic poetry', ${ }^{35}$ discusses the deep relationship between the landscape and the Gaels - a landscape rich in meaning on many levels:

The native Gael who is instructed in this poetry carries in his imagination not so much a landscape, not a sense of geography alone, nor of history alone, but a formal order of experience in which these are all merged. The native sensibility responds not to a landscape but to dùthchas. And just as 'landscape', with its romantic aura, cannot be translated directly in Gaelic, so 'dùthchas' and, indeed dùthaich' cannot be translated into English without robbing the terms of their emotional energy. The complexity involved can be appreciated by reflecting on the range of meaning: dùthchas is ancestral or family land; it is also family tradition; and, equally important it is the hereditary qualities of an individual. ${ }^{36}$

The landscape the Gaels so fervently long for in many of the songs is an inscribed one-a landscape imagined replete with cultural references and significances built up over generations of intimate contact and held as a potent, yet static force in the mind of the exile.

As this paper shows, for many migrants the removal from geographic place is a painful one, for we have a profound attachment to the things that form us. Our connection to place is strong, and the past is not only rooted deep in the soil of a physical landscape, but is also retained in the memory: an imagined landscape that carries our past forward. This imagined landscape reshapes and reforms itself, polished and transformed in the mind to something that may not have much in common with the original-yet, for the migrant, it imparts comfort and solace, and provides a sense of continuity and identity within a

\footnotetext{
34 For some interesting ideas on intertextuality and music, see Klein, Michael 2005, Intertextuality in Western Art Music, Indiana University Press, Bloomington. Further discussion of this topic is beyond the limits of this particular article.

35 MacInnes, 'The panegyric code in Gaelic poetry' (in Dùthchas Nan Gàidheal, pp. 265-319).

36 Ibid., p. 279.
} 
fractured past. The landscape of the imagination to which the Scots Gaelic exiles repeatedly turn is a retreat, a place of refuge: an escape (albeit temporarily) from 'the merciless pain of homesickness', as the bard John Archie so poignantly put it. In a sense, this imagined landscape is divorced from reality, yet it retains a deep connection with the past, ensuring an ongoing sense of identity for Scots Gaelic migrants in Australia in times of great change and turmoil.

\section{Bibliography}

An Teachdaire Gaidhealach, [Hobart], nos 1-9 (1857).

Basu, Paul 2007, Highland Homecomings, Routledge, Oxford.

Bowring, Jacky 2010, 'Eternal sunshine: the search for spotless landscapes', in Janet Stephenson, Mike Abbott and Jacinta Ruru (eds), Beyond the Scene: Landscape and identity in Aotearoa New Zealand, Otago University Press, Dunedin.

'Ceud Soraidh Bhuam gu Barraigh' ('My Blessings on Barra') 1970, Tobar an Dualchais: Kist o Riches, viewed 10 April 2012, <http://www. tobarandualchais.co.uk/en/fullrecord/82141/2>

Collinson, Francis 1966, The Traditional and National Music of Scotland, Routledge and Kegan Paul, London.

Devine, T. M. 1999, The Scottish Nation: A history 1700-2000, Viking, New York.

Gibson, R. 2006, The Highland Clearances Trail, Luath Press, Edinburgh.

Lowenthal, David 1975, 'Present place: landscape and memory', Geographical Review, vol. 65, no. 1, pp. 1-36.

Lowenthal, David 1985, The Past is a Foreign Country, Cambridge University Press, Cambridge.

Lyle, Emily 2009, 'Luchdàiteachaidh an Astràlia [Pioneers in Australia]', Tocher, vol. 59, pp. 26-34.

Martin, Ruth Lee 2011, 'Leaving makes me sorrowful', in Graham Seal and Jennifer Gall (eds), Antipodean Traditions: Australian folklore in the 21st century, Black Swan Press, Perth.

Withers, Charles 1988, Gaelic Scotland: The transformation of a culture region, Routledge, London. 